\title{
MiLitary STRESS, CENTRAL POWER AND LOCAL RESPONSE IN THE COUNTY OF CASTILE IN THE TENTH CENTURY
}

Julio Escalona ${ }^{1}$

This chapter aims to explore the role of fortifications in the southern fringes of the county of Castile bordering the river Duero, a region well known for its intense military activity during the tenth-century. The region and period provide an excellent case study to address some of the issues addressed by other chapters in this volume, including the construction and function of defence systems, the role of central power therein, or the impact on, and response of local society to those developments. The Duero border is particularly interesting because of the suddenness of the processes that turned a distant, much fragmented periphery into a major military frontier of the Asturian kingdom against the Caliphate of Córdoba. In the following, I will argue that tenth-century fortifications in this region are the result of a variety of inputs, some of which derive from centralised operations, while others respond to local initiatives, in a context of intense social change, largely triggered by military stress and incorporation into a larger-scale, more complex political system.

\section{The Duero Basin in the Early Middle Ages: From Post-Roman Fragmentation to the Asturian Expansion}

The ending of the effective control exercised by the Roman state in the north-western quadrant of Iberia was abrupt. The region never achieved an economic or social development comparable to those of the richer areas of Baetica or the Mediterranean coastal lands, and much of its articulation depended on the resources and structures provided by the state (Escalona 2006). When those failed, in the first quarter of the fifth century, the impact was both sudden and intense: in about one generation a process of urban decline set in almost everywhere, combined with the massive abandonment of villa-

\footnotetext{
${ }^{1}$ This text was prepared with funding provided by the Spanish Ministry of Education and Science (project of the Plan Nacional de I+D+I "The Foundations of the European Space: community, territory and political system in Early Medieval Europe"; ref: HUM2004-01812/HIST). A preliminary version was presented to the Landscapes of Defence conference at the UCL Institute of Archaeology. I am grateful to all those who attended and provided feedback and comments. I am likewise indebted to Isabel Alfonso, Juan Antonio Quirós and Andrew Reynolds for their comments and suggestions. None of the above mentioned is responsible for any errors it may contain. Charter collections are cited by the following abbreviations and editions: Cardeña (Martínez Díez 1998); San Juan de la Peña (Ubieto Arteta 1962).
} 
sites, especially the grandest ones (Chavarría Arnau 2007). The recent boom in the archaeology of rural peasant sites is beginning to build the case for a wholesale reorganization of settlement and land-use, along the main lines of community links, rather than evolving from the great landed properties, following the fifth-century crisis of Late Roman landscape organisation (Quirós Castillo and Vigil-Escalera Guirado 2006; VigilEscalera Guirado 2006). In parallel, the large urban territories of the Roman period became fragmented into smaller ones as most towns failed to keep control of their hinterlands and smaller centres appeared, sometimes within re-occupied pre-Roman fortifications, sometimes within newly founded castra (see Quirós, this volume). The production and circulation of goods became similarly fragmented (Escalona 2006). The region's elites, thus, shrunk from their former urban scale to much smaller, unconnected networks directly controlling very small territories and communities, but with little capacity to build power connections on a larger scale. Therefore, the former urban network could hardly keep playing its crucial intermediary role of connecting central government with the local scale. This connection became increasingly dependent on the direct links that could be established between the state and a large number of obscure micro-regional aristocracies, perhaps by means of their participation in state affairs such as taxation (Castellanos García and Martín Viso 2005).

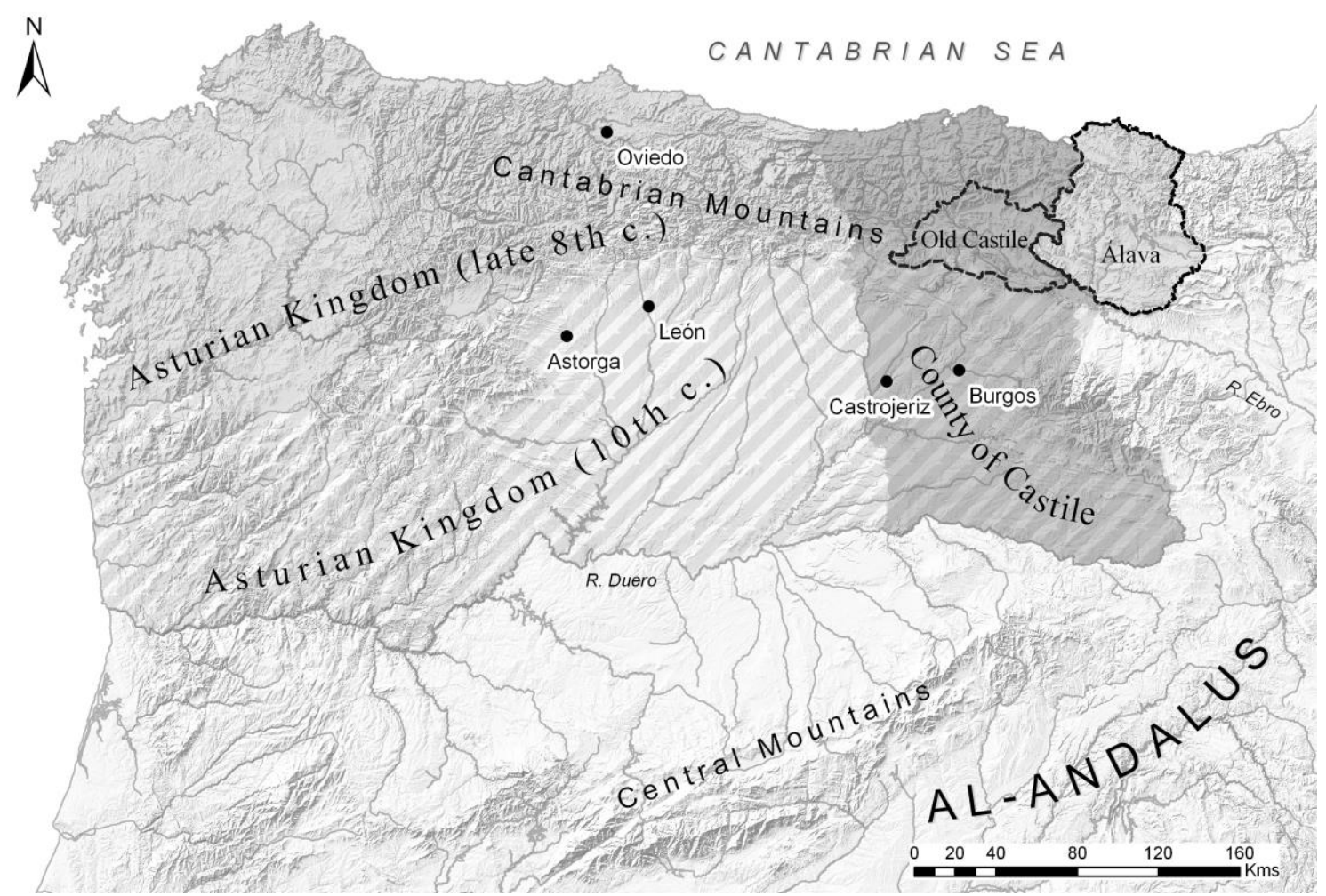

Fig. 13.1. The expansion of the Asturian Kingdom in the Duero plateau, eighth to tenth centuries. On the eastern side, the territories of Álava and Castile are represented, the latter showing both its original extent and its expanded limits. Map by J. Escalona.

The period between the mid-fifth and mid-sixth centuries was dominated by the almost total absence of a central power for those fragmented elites to interact with, especially on the eastern side of the Duero basin. Not without problems, the Suevic kingdom managed to control the westernmost areas and slowly create a small polity there, while the rest of the region remained a remote periphery, beyond the Sueves' reach, largely beyond Visigothic control too, and far away from the more dynamic areas of Baetica, Lusitania 
or Tarraconensis, where cities - despite the damage caused by the disruption of their longdistance connections (Wickham 2005, 744-746; Carr 2002) - retained some capacity to control their territories in a period with little or no centralized rule (Arce 2005, 213-234 and 279-280). The consolidation of the Visigothic monarchy at the end of the sixth century (including the conquest of the Suevic kingdom in 585) probably tempered the northwest's trend towards de-structuration, but building stable exchange links between the central power and a large number of extremely heterogeneous small-scale powers was difficult (Martín Viso 2008) and the region remained largely inarticulate. During the eighth century a deeper crisis of central power started following the destruction of the Visigothic monarchy by the Arabs in 711 and the latter's failure to develop stable political bases north of Iberia's Central Mountains, and thereafter the process of fragmentation soared to its maximum in the Duero basin (Escalona 2006).

On the evidence of written sources - mainly the dry, ideologically charged lateninth century Asturian chronicles - it is possible to draw a sketch of political developments in Iberia's mountainous north from the mid-eighth century (fig. 1). By the last third of the eighth century, most territories north of the Cantabrian mountains had seemingly become incorporated into a single polity dominated by the kings of Oviedo, although the foundations of such a convergence remain largely conjectural (Fernández Conde, Suárez, and Gutiérrez 1997), especially considering that until the ninth century very few advances by way of governance or territorial organization can be detected (Estepa Díez 2002). As of the mid-ninth century a strengthening of royal power becomes perceptible, with the articulation of a sphere of high-ranking aristocrats in the royal entourage (comites) and, perhaps, the appointment of territorial delegates (Estepa Díez 1992).

This process had military consequences. In the late eighth and early ninth centuries, when Carolingian involvement in Iberian affairs was at its highest (Fernández Conde and Loring García 1997; Escalona 2004), the consolidation of the Asturian kingship meant a significant change in the peninsular power balance. Tellingly, the newly established Ummayad emirate started to launch military attacks from their strongholds in the middle Ebro valley against their western neighbours, probably through the same passes that the old Roman road system had used to connect the Ebro valley with the plateau. Whether the target was the kingdom's core or just to castigate the frontiers, the lands in the immediate vicinity of the Muslims usually took the first blows in every campaign (see detailed discussions of military strikes in Sánchez-Albornoz 1950; Martínez Díez 2004). More than fifty years after the beginning of continued warfare, we learn that in the eastern borders of the Asturian kingdom there were at least two different territories: Álava and Castile, of which the first seems to have been slower to integrate in the kingdom's structure (García de Cortázar y Ruiz de Aguirre 1997). As for Castile, originally it was a small area (later called 'Old Castile') in the mountainous north-eastern fringes of the Duero basin (Martínez Díez 2004). By the mid-ninth century, Latin and Arabic texts begin to call this area 'land of castles' [Lat. Castella, Arab. al-Qila', both meaning literally 'the castles', in the plural], and a passage in Alfonso III's Chronicle (880s) suggests that it had changed its former name from Bardulias to Castile: 'Barduliae quae nunc appelatur Castella' (Chronicle of Alfonso III, 14 (Gil, Moralejo and Ruiz de la Peña, 1985)). Whichever came first, both the Latin and the Arabic term coincide in highlighting an abundance of castles in this small northern territory, of which Tedeja or Buradón (fig. 2) may be examples (see Bohigas Roldán and Lecanda Esteban 2000; Quirós, this volume). It is hard to be precise, though, whether the creation of those fortifications was an initiative of the Oviedo kings to protect their most threatened frontier or, instead due to the region's elites, who, in the context of mounting military stress, 
sought to protect themselves and, conceivably, to gain royal favour by doing so. In whichever case, it seems clear that in the ninth century Álava and Castile were military targets for the Arabs chiefly because they had been incorporated to the Asturian kingdom as important frontier positions (Fig. 13.1).

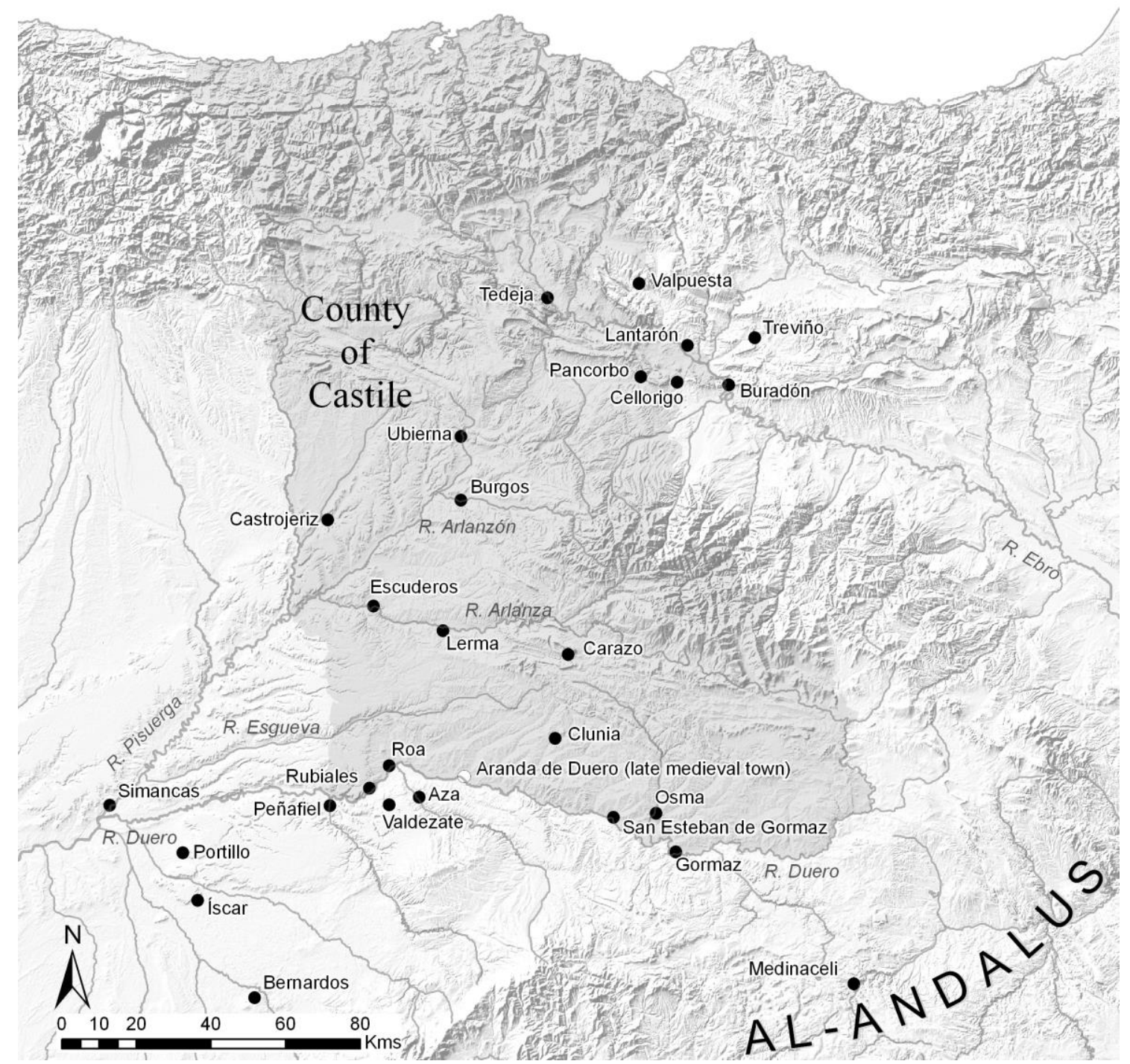

Fig. 13.2: The County of Castile in the tenth century, showing the main places cited in the text. Map by J. Escalona.

By contrast, no similar attacks are recorded in this early period in most of the plateau lands of the Duero basin, which still remained beyond Asturian control and therefore posed no threat to the Emirate. In those areas, by lack of any centralizing power, whether Christian or Muslim, no large- or medium-scale polities seem to have existed. A retrospective reading of the process by which the plateau was incorporated into the Asturian kingdom in the late ninth and early tenth centuries strongly suggests that the region was dominated by a scatter of micro-territories which in many cases - but not all - provided the building blocks for the creation of the tenth-century network of administrative districts called alfoces (Estepa Díez 1984; Álvarez Borge 1993, 55-98; Martín Viso 2000, 128-130; Escalona 2002, 229-230). From the analysis of those districts, 100-150 sq km seems a reasonable average size for the territorial units of the Duero plateau. Their remarkably simple spatial structure consisted of just two hierarchical levels: the first being a scatter of rural settlements, usually centred on the second, which 
consisted of one higher-status settlement, normally a hill-top site. This is reminiscent of the Late Pre-Roman Iron Age socio-political articulation of the Duero plateau, which, of course, means no 'Celtic revival', but rather a comparably small scale of socio-territorial articulation. Even though there is some evidence for social inequality in those petty polities, given their limited size and simplified economic and social structures, there was probably very little room for internal differentiation, especially for the elites. It seems likely that social interactions, as well as status and power relationships mainly operated within a framework of community structures that largely conditioned their incorporation to the Castilian county in the tenth century (Álvarez Borge 1987, 1996; Escalona 20002001). For much of the eighth and ninth centuries, those small-scale supra-local communities seem to have existed without becoming integrated into larger polities, although both the Asturian kingdom and the Emirate may well have wielded influence beyond their respective borders - a sort of 'buffer effect' - perhaps attracting the plateau communities into some kind of cooperation. This could perhaps be reflected in some striking cases like the prominent fortification at Bernardos, in the province of Segovia (Gonzalo González 2007, Quirós, this volume) or the recently suggested pre-Caliphal phase at the Gormaz castle, in the province of Soria (Almagro 2008) (Fig. 13.2).

\section{Changing Scales, Changing Horizons}

The impact of the Asturian kingdom's expansion over the northern half of the Duero plateau (fig.1) can be considered at different scales (see a more thorough discussion of scale change in this region in Escalona and Reyes Téllez 2011). Between the mid-ninth century and the 880 s the lands between the Cantabrian mountains and the old Roman road that led from Aquitaine to the former Roman capital Asturica Augusta (Astorga, Prov. León) were firmly incorporated, and $c .900$ the lands down to the river Duero had been absorbed. This meant that the Asturian kingdom grew by roughly a factor of 2.2 from what it had been at the end of the eighth century. On the eastern side, the process was somehow delayed; the Castilian counts did not reach the Duero line until c. 912 (fig. 2). It was a dramatic change, nevertheless: the newly acquired lands meant a shift in the order of roughly ten times, compared with the mid-ninth century district called Castile. However, this is a moderate leap compared with the intensity of the change when considered from a local perspective. The territorial horizons of the small-scale societies that occupied the lands between the rivers Arlanzón and Duero were in the order of 100$150 \mathrm{sq} \mathrm{km}$ - to judge by the size of the smaller tenth-century alfoces -, and they suddenly became engulfed into a social-political system more than 500 times larger. Their whole cultural framework changed abruptly in the course of two generations, as they had to adapt to an entirely different social system that was itself quickly gaining complexity (Díez Herrera 1999).

If we first set the focus on Castile's highest social sphere, the period $880 \times 930$ stands out as one of dramatic transformations for the whole Castilian county, as it expanded southwards. The so-called First Castilian Annals (940s) provide a simplified, two-stage glimpse of this process: first an advance down to the river Arlanzón in the 880s, then another down to the Duero in 912 (fig.2). ${ }^{2}$ Despite the emphasis of written sources

\footnotetext{
${ }^{2}$ Anales Castellanos I (ed. Gómez Moreno 1915):

- s.a. 882: In era DCCCCXX populavit Didacus commes Burgus et Auvirna pro iussionem domno Adefonso. $[\ldots]$

- s.a. 912: In era DCCCCL populaverunt commites Monnio Nunniz Rauda et Gondesalbo Telliz Hocsuma et Gundesalbo Fredenandiz Aza et Clunia et Sancti Stefani iusta fluvius Doyri.
} 
on royal initiative, the overall move - especially the second phase - is better understood in terms of an expanding aristocracy. Tellingly, the period that followed 912 was one of intense competition among aristocrats - the three counts of the 912 Annal entry and others - for control of the newly acquired lands and for supremacy within an expanded Castilian territory. The best example is probably Count Gonzalo Téllez, studied in detail by I. Martín Viso (2002). The ruler of a small area between Álava and Castile, where he held extensive rights over land, peasants and resources, controlled monasteries and even had in his entourage the bishop of the small see of Valpuesta (Martín Viso 1999). Gonzalo Téllez took active part in the expansion southwards and, in doing so, he became a magnate at the largest possible scale in early tenth-century Castile. He added to his resources control over territorial centres like the erstwhile Visigothic episcopal town of Osma; before his death, c. 915, he founded or patronized monasteries and gained substantial blocks of property in the surroundings of Burgos, the county's political centre. This example illustrates how the highest Castilian aristocrats took advantage of the expansion to transform themselves from sub-regional elites into large-scale lords, military leaders and great landowners, ever less like chieftains and more like a feudal ruling class. This trend crystallized around 930, when some kind of consensus terminated the previous phase of competition and a single leadership by Count Fernán González was established - not without some resistance - in all of Castile and Álava. Thereafter, the tenth-century Castilian charters yield the picture of an aristocracy of remarkably low political profile the counts appear to take all the credit for this - but mounting landed interests, based not only upon landownership but also upon the control of a growing class of dependent peasants (see Estepa Díez 1989, pp. 191-96, on lords-to-peasants relationships).

When seen from a bottom-up perspective, the transformations look no less dramatic. Inasmuch as we can envisage it, before the Castilian expansion the small communities of the Duero border had a basically twofold social structure, of freemen and their elites. We cannot rule out the existence of unfree people or small-scale slavery, but the evidence is thin (Martínez Díez 2007, esp. 587-592; Cfr. Pastor Díaz de Garayo 1996, 280-88). Given these societies' very limited scale, it seems likely that members of the elite were also farmers themselves, even if they had access to more lands and extra workforce by means of their control of kin relations and community leadership (Escalona 2000-2001; Wickham 2005, 542-43). However, the overarching social system into which those areas were incorporated after 912 was much more complex and unequal. Besides, for the crucial generation that lived through the great changes of $c$. 910-930, the convergence between both social systems created an outstandingly open period in which hierarchies and individual positions were more open to negotiation than they would be thereafter. For the regular farmers of the Duero borders the options were limited. Their rural communities were very similar to many others across the county, and their integration in the widespread class of free landowning peasants seems rather straightforward. Alternatively, they could become more directly subjected - whether collectively or individually - to some higher lord (the counts, an aristocrat, an ecclesiastical lord) and join the class of dependent peasants, a process that progressed continuously across the tenth century and later. Instead, the options for the local elites were wider. If they stayed where they were, the most obvious choice was to remain within the community framework and become a part - arguably the upper, richer layer - of the free peasantry, but if things turned out badly, they could even end up as dependent peasants, especially in the rather infrequent case of local communities collectively 
subjected to one lord. ${ }^{3}$ They could instead take action and seek a more favourable insertion into the new order. True, no petty leader of the Duero borders could stand comparison with aristocrats like Gonzalo Téllez described above, so there was no obvious pathway from local leadership to the large-scale aristocratic class. However, aristocratic power largely rested upon clientele networks that had to be re-sized after the expansion to reach the local contexts, which required cooperation from the localities, something that clearly rested in the hands of their elites.

For the communities of the Duero borders, the Castilian expansion meant subjection to a larger, more unequal social-political system, but many of the impositions and burdens that landed on them could be seen also as opportunities for their local leaders to climb up the social ladder and join the lower ranks of the ruling class (see below). This possibility, however, was clearly not available to everyone, so it seems likely that a period of competition among local elites developed roughly at the same time that a similar struggle was going on among the aristocrats. Of the many elements that the new situation brought about, warfare probably meant the greatest resource for the local elites, which, by reinforcing their control over their communities, could appear as suitable collaborators before the counts and other aristocrats. It seems adequate, thus, to consider the different levels in which warfare affected the socio-political re-structuring of the Duero borders in this period.

\section{Warfare and Society on the Duero Border in the Tenth Century}

By focusing on the newly created southern frontier of the Castilian county, we can observe how warfare and fortifications reflect the dialogue between levels of political articulation.

\section{Major fortified strongholds}

Perhaps the most visible aspect of this process was the creation of a number of major strongholds that eventually converged into a defensive network of which they became the leading nodes (Gutiérrez González 1995, 124-133; 2000). The earliest moments of this process on the Duero border are badly documented, but we can compare the situation with the case of Castrojeriz, rather far north from the river Duero, which was occupied and fortified in the 880s phase of expansion. The Chronicle of Albelda illustrates how in 882 the place, recently occupied by Count Munio Núñez, was plundered by a Muslim army before its defences could have been erected. The next year, a similar raid met a properly defended site that was able to resist:

In the reign of the aforesaid prince [Alfonso III], in the era 920 [882 AD], the aforesaid Almundir, son of King Mohamed, was sent by his father together with General Abuhalit and a force of 80,000 men, and he proceeded from Córdoba to Saragossa (...). This very army, having arrived at the borders of Castile, by the castle called Pancorbo, first laid siege to it for three days, but with no success (...). Also Munio, son of Nuño, deserted Castrojeriz on the Sarracins' arrival, as it was not yet fortified enough. (The Muslims then proceeded to the vicinity of León)...

... After that, in the era 921 [883 AD], which is the current year, the aforecited Almundir (...) with the whole army of Spain, was sent by his father to attack Saragossa (...). Thereafter the same army

\footnotetext{
${ }^{3}$ This may be the process underlying the case of a woman called Mayor, from the Riojan village of Terreros, under the lordship of the abbey of San Millán de la Cogolla, who was defeated in court when she claimed noble status (Loring García 2005).
} 
entered our kingdom's territory and they first fought the castle of Cellorigo, where many of their lot were killed. Count Vigila defended this fortress. He then proceeded to Castile, to Pancorbo castle where he started the fight by his own accord, but after the third day he was defeated and had to leave it. Diego was the Count. He then found Castrojeriz well defended and he could not do anything there, and in the month of August he approached the borders of León. ${ }^{4}$

These passages illustrate the haste with which new fortifications were established in a frequently attacked area. Thirty years later, warfare had largely moved south to the river Duero border, where we can imagine similar processes taking place in the occupation of the defensive sites cited in the aforementioned Annal entry for AD 912: Aza, Roa, Clunia, San Esteban de Gormaz and Osma (fig. 2). This move has been traditionally explained as a carefully planned operation commanded by King García, and carried out by three of his counts, leading to the establishment of a fully articulated defensive line on the river Duero (Pérez de Úrbel 1951, 142-144), but it is now rather seen as several separate initiatives perhaps conflated into one single Annal entry - that only came to constitute an integrated defensive system after a period of adaptation. Before 965, the fortress of Gormaz may have played a leading role in the upper Duero, on the evidence of the emphasis of certain Arabic sources recording the deaths in battle of successive Gormaz rulers, that they call counts (Ibn Hayyan 1981, 230, 298, 326). By the same time, according to Ibn Hayyan, Lerma (on the river Arlanza backline) acted as an organizational centre for Castilian offensive operations:

In his victory report of this campaign [the 934 raid against Castile, actually a major defeat for the Caliph] an-Nasr mentioned the regions of Álava and Castile he had crossed, among them (...) the big and well-built city of Lerma and its important surrounding plains, which was found deserted, and all palaces and churches in it were destroyed. This used to be the starting point for all of the enemy's raiding troops that were sent against the Muslims' country, and there they used to divide among themselves the booty and captives they took (Ibn Hayyan 1981, 231). ${ }^{5}$

After 965, when Gormaz was seized by the Caliphate, other places like Peñafiel, Clunia and Carazo became the main military centres of the frontier (see below). However, it is not clear that the same scheme already operated in the few first years after 912 . In fact, Muslim attacks on the Duero line did not start immediately. The first raid recorded was on San Esteban de Gormaz in 917, followed by another on Osma, San Esteban and Clunia in 920. Thereafter, military stress on the Duero borders became ever more frequent, concentrating in the periods 929-961 and 977-1002 (Escalona 2000-2001; on the latter phase see Isla Frez 2000). Nevertheless, the picture of a continued defensive line on the river Duero does not quite work, even in those particularly eventful periods, as the distribution of strongholds along the river seems to form not one line, but two clusters, one in the east and another in the west, with a gap in between around the modern town of Aranda de Duero (see fig. 2 and Escalona 2000-2001). The next cluster is to be found further west in the area around Simancas, with fortified sites such as Íscar and Portillo (see fig. 2 and Escribano Velasco and Balado Pachón 2000).

Although most can be located as dots on a map (fig. 2), archaeological recognition of these major fortresses is still crudely underdeveloped (Quirós, this volume). The main difficulty is that most of them were long-lived as fortified sites, so the tenth-century defences - and whatever earlier structures they replaced - became largely masked by the bulkier castles of the central and late middle ages. A traditional disregard for the early medieval period among archaeologists has also played its part. Thus, in highly relevant

\footnotetext{
${ }^{4}$ Chronicle of Albelda, 14 (ed. by Gil, Moralejo, and Ruiz de la Peña 1985). English translation is my own.

${ }^{5}$ English translation is my own.
} 
places, like Castrojeriz or Burgos, the best-recorded phases belong to the late medieval castles and the late prehistoric walled settlements that preceded them (Abásolo Álvarez and Ruiz Vélez 1976; Abásolo Álvarez, Ruiz Vélez, and Pérez 1983; Uribarri Angulo, Martínez González, and Leis Muñoz 1987; Escribano Velasco, Balado Pachón, and Pascual 2000, 775-776), while the early medieval phase is hardly investigated at all. The recently recognized, yet unpublished early medieval phase of the fortification at Treviño, in northern Castile (Quirós, personal communication and this volume), so far lacks a comparable counterpart in the south of the county. Halfway between Burgos and the river Duero, fortified sites like Lerma or Escuderos (a deserted site near Santa María del Campo, Burgos), offer hardly any archaeological records at all. On the Duero line, most strongholds present similar problems. In the western cluster, in Peñafiel, much modified by the huge late medieval fortress there, only a preliminary recognition of early medieval material was done in the 1970s (Lucas de Viñas 1971). In Roa, where the medieval walled town overlays the early medieval site, most archaeological activity has concentrated on the late prehistoric oppidum beneath. Aza poses similar problems, although recent unpublished fieldwork suggests a remarkable change in settlement patterns following the organization of the frontier in the tenth century (Ángel Luis Palomino, personal communication). Less prominent sites, like Rubiales (San Martín de Rubiales, Burgos) have been recognized as probably belonging to the same group, but no large-scale excavation has been carried out (Reyes Téllez 1997). In the eastern cluster, the case of Clunia is especially striking. In the first century, Clunia was the capital of a conventus iuridicus that centralized the administration of most of the eastern Duero plateau. The city experienced a sharp decline in the fifth century, and seems to have played no relevant role in the Visigothic period (Cepas Palanca 2006). However, in the tenth century Clunia begins to be mentioned again as an important centre of the Duero border, of which it became the military capital in the later tenth century. ${ }^{6}$ By this time, its location seems to have shifted from the great tabular promontory where the Roman town lay to a more modest elevation nearby, where the only fortified elements yet recognized belong to the ruins of the late medieval castle. The upper Duero valley is the only section that provides a more coloured picture. In this stretch of the frontier there was continued contact between the Castilian county and the Caliphate (Manzano Moreno 1991, 346-370). As the first consolidated its control north of the river, the latter intensified its military presence in the area, working from the regional centre of Medinaceli, and created a dense network of fortified sites and ancillary surveillance points. Between 965 and 1011 the main element on the Andalusi side was the huge fortification at Gormaz, which was their leading military centre and the basis of an offensive that led to the seizure of several Castilian strongholds in this area, like San Esteban de Gormaz or Clunia itself in 994 (Escalona 2000-2001). The sheer prominence of the Gormaz defensive structures -together with a traditionally stronger emphasis on Islamic archaeology - explains why sites like Gormaz have been more thoroughly investigated than their Castilian counterparts (Gaya Nuño 1943; García Merino 1973; Almagro 2008). Likewise, a number of surveillance sites belonging to the Caliphate's defensive network in this area have been recognized in the modern province of Soria (Zozaya Stabel-Hansen 1984, 2008).

\section{Watchtowers}

Even less is known of the defensive system surrounding each major fortress on the Castilian side. Although in recent times increasing attention has been paid to surveillance

\footnotetext{
${ }^{6}$ As early as 920, Arabic sources describe a prosperous city, surrounded by a well organized agricultural landscape (Ibn Hayyan 1981, 107).
} 
and alert systems on Al-Andalus's north-eastern frontier (Martí Castelló 2008), very little research is available for Castile along this line (Villalba y Ruiz de Toledo 1996; Lecanda Esteban, Lorenzo Arribas, and Pastor Díaz de Garayo 2008). The border strongholds, subjected to repeated attacks and destructions, obviously needed some alert system in the case of an Andalusi army approaching, and the implementation of a surveillance service (see below) points in the same direction. Hitherto, an articulated system of watchtowers has been suggested only for the border's western cluster, in the vicinity of Roa, Aza and San Martín de Rubiales, on the basis of the survey of a number of points apparently aiming to visual coverage of the valleys approaching the Duero line from the south (Reyes Téllez and Menéndez Robles 1987) and on the excavation of one such site: the tower at Valdezate (Burgos). The Valdezate tower is difficult to interpret not only because of the site's inherent problems, but also for its lacking any comparable counterpart in the region so far. It is placed on top of the plain uplands south of the Duero, about $180 \mathrm{~m}$ above the valley bottom, in a position that keeps perfect visual contact with the main fortress at San Martín de Rubiales and controls the narrow valley of the river Corcos, the obvious approach from the south (fig. 13.3). The two-storeyed stone building erected there was enough to house a small garrison of up to a dozen men, but the site lacked any walled enclosures - with the possible exception of a palisade - where the local population could take refuge (for details see Reyes Téllez 2000, vol. 1, 348-352). It was clearly not meant to resist attack, but to provide early alert to the Rubiales fortress. This seems to be exactly what happened in its final phase. The building was deserted in haste by its garrison, who took all portable valuables with themselves, but abandoned more burdensome commodities before the tower was destroyed and set ablaze, with no signs of resistance (for the possible historical contexts of this destruction, see Reyes Téllez 1997). The greatest problem of the Valdezate tower is its chronology. Only one occupation phase was recorded, and the abundant, coherent material culture recovered also suggests that the site was not in use for a very long period. The pottery is in tune with survey and excavation findings at other sites nearby, and it could well fit a tenth-century date, but our knowledge of eighth- to eleventh-century ceramics in this region (Menéndez Robles 1991; Larrén Izquierdo et al. 2004) does not yet allow anything but the coarsest of dating (tenth to eleventh century, for example). On the other hand, recent attempts to obtain radiocarbon dates for this site (unpublished) have proved inconclusive. An occupation date within the first third of the tenth century remains likely, but must be treated as conjectural until more solid data are obtained. If hypothetically accepted, the Valdezate tower would be the only example yet of how the second level of defence was implemented in the Castilian Duero border. The tower clearly could not serve as refuge for locals; its main visual advantage was to provide control for the Rubiales fortress, a function easily fulfilled by a small group of men working in shifts, especially in the summer season, when Muslim raids usually took place; it could not, and did not, resist a serious attack. The question whether Valdezate is archetypical could be investigated by further reconnaisance along the southern side of the Duero valley in search of similar watchtowers. This of course, does not exclude the existence of other minor, unfortified alert points, like beacons, whose existence is difficult to demonstrate archaeologically. 


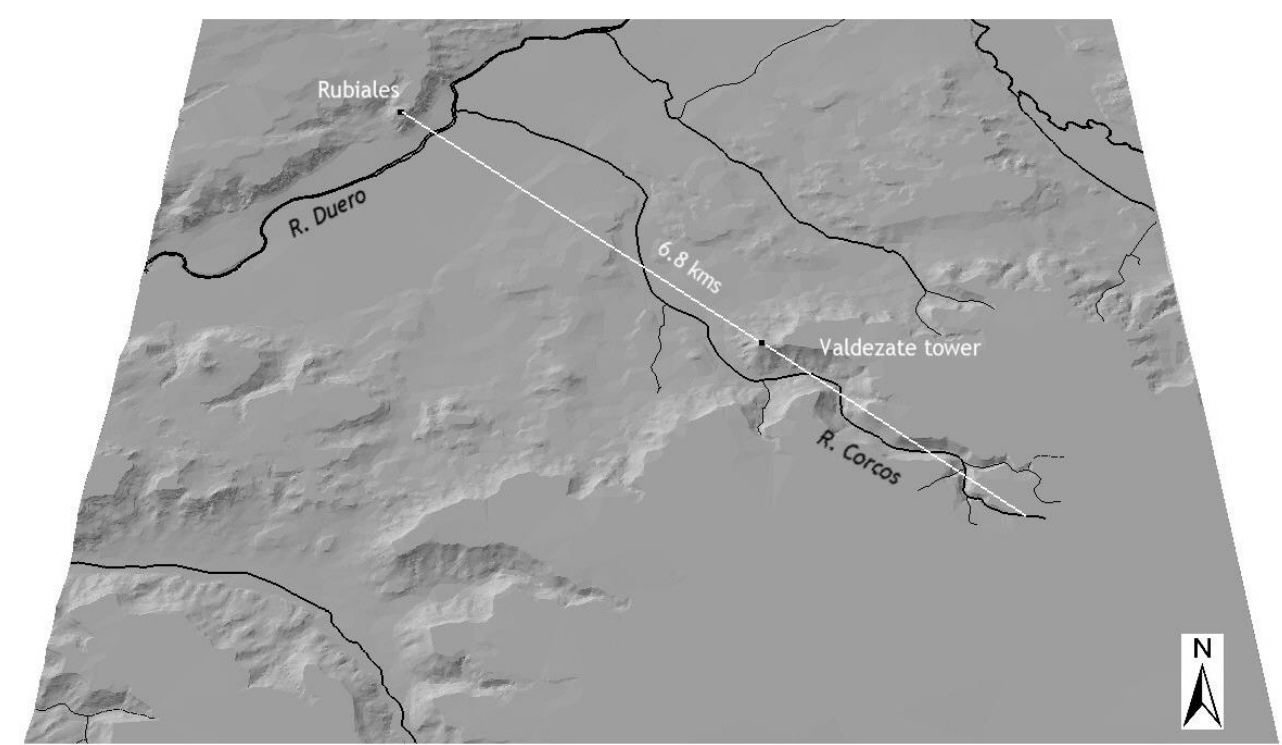

Fig 13.3. Location of the Valdezate tower in relation to the nearest central place (Rubiales) and to the control of the main approach route from the south-east. Map by J. Escalona.

\section{Territorial control and military obligations}

Sites like Osma, Clunia or Roa were more than just the upper layer of fortifications in the region. Most of them were the centres of the districts (alfoces) into which the county was divided, although we cannot ascertain how swiftly this administrative network was established (Álvarez Borge 1993, 201-209; Escalona 1997). In most cases the existing territorial communities probably provided the basic layout, so district centres may somehow reflect the region's pre-912 organization, but this is not always the case, as sometimes large districts were created that engulfed several earlier units. The best example is Clunia, whose huge alfoz certainly absorbed - and to a great extent obliterated - other territories, but this seems to have happened not in this early phase, but rather in the late tenth-century period of most intense military pressure on the Duero border (Escalona 2000-2001). During the tenth and eleventh centuries, the documentary evidence yields an image of the twofold workings of alfoz centres: on the one hand, they were political and administrative centres, controlling a territory and its resident population, which at the time meant not so much tax-collecting as the exercise of justice and military leadership; on the other hand, alfoz centres were also the basis for the management of the Castilian rulers' increasingly extensive estates, so the revenues from whichever property they held within a given territory were collected at those sites. This neat image is largely late tenth- or early eleventh-century in date. The evidence is too patchy to describe the pace at which this system was established, but it seems that at least political jurisdiction (judicial and military), as well as the power to control communitymanaged elements of the local economy, were present from the very start, though probably more through negotiation than coercion.

Given the importance of warfare in the Duero frontier, the procedures of army raising and military obligations are especially relevant (an overview in English in Halsall 2003, 84-85). There is no single text that describes them in detail, but they can be deduced from a number of individual allusions. Eleventh century charters recording exemptions from such burdens are especially eloquent, but they may well project a late, more evolved situation, despite the early examples commented by Sánchez-Albornoz (1968, 382-387). It is generally accepted that the counts of Castile were entitled to military obligations performed by the county's free population, much like the trinoda necessitas of AngloSaxon England (Brooks 1971; Abels 1988). The most general obligation was called 
fossatus (in Latin) or fonsado (in Castilian) that is, participating in the Count's army - or the King's, in the rare occasions in which he personally led the army in Castilian territory (Sánchez-Albornoz 1968, 396-401). Fonsado normally entailed participating in military operations anywhere they could take place, so it was not a local affair (the duty to participate in a locality's immediate response to attack was called apellido and it seems to have been a smaller-scale affair). In time, as the frontier and its associated stresses moved south, fonsado became increasingly limited by local legal codes and ultimately converted into a tax called fossatarialfonsadera, which represented the duty to pay for exemption from actual participation in warfare (Estepa Díez 2006; 2003, 238-245; 1996). Since at least the eleventh century, non-noble participation in fonsado was organized in two levels: horse-riders (equites) and infantry (pedones), reflecting the twofold status division of Castilian local communities, but this neat division probably did not operate yet in the early period.

The second general military obligation was called castellaria and it entailed providing the workforce for the building and maintenance of castles (Sánchez-Albornoz 1968, 402-403). We cannot be sure how this work render was organized in the early period, but the later evidence, spanning well into the later middle ages, again in the form of a converted tax, indicates that it was based upon the territorial network: the inhabitants of each district were responsible for the maintenance of its castles. We know only one tenth-century case in which the population of an alfoz was exempted from labore de illos castellos by the Count of Castile in $972,{ }^{7}$ which highlights the general character of the burden in this period (Sánchez-Albornoz 1968, 403).

The third general military obligation was called anubda and it meant providing garrisons for surveillance (González de Fauve 1964; Sánchez-Albornoz 1968, 403-408). Twelfth-century local codes refer to this obligation as a job fit for commoners, rather than knights, but in the tenth-century this seems to have been a specific task of the frontier's local elites. In the early tenth century anubda was arguably performed on a more decentralized basis, perhaps organized from each district's fortress. ${ }^{8}$ However, as warfare on the frontier intensified, it started to work at a larger scale, especially in the late tenthcentury, when the performance of anubda was centralised in the two major fortresses of Peñafiel in the west and Carazo in the east, where the region's infanzones [petty knights] were summoned periodically, as described by the unusually colourful narrative of a $c$. 1030 document (Escalona 1987):

Those infanzones of Espeja [a small area in the alfoz of Clunia] had the obligation to perform anubda in Gormaz, Osma and San Esteban. When those castles were taken by the Moors, Count Sancho ordered them to pay their anubdas in Carazo and Peñafiel, like all infanzones did. ${ }^{9}$

The creation of the frontier and the imposition of military obligations upon the population in the Duero border are both consequences of its incorporation to a large-scale political system, which also entailed other major changes, like the implementation of a superior judicial system, and the infiltration in the local scene of aristocratic landholding networks that had a great potential in the long run to modify existing socio-economic relationships. We can hardly doubt that, in general terms, the result was a huge increase in the burdens

\footnotetext{
${ }^{7}$ Cardeña, $n^{o} 153$ (ed. by Martínez Díez 1998).

${ }^{8}$ If an early tenth-century date is confirmed for the aforecited Valdezate watchtower, this could be a good setting for $a n u b d a$, in connection with the fortress at San Martín de Rubiales (fig. 3).

${ }^{9}$ San Juan de la Peña, no 54 (ed. by Ubieto Arteta 1962): Ipsos infanciones de Spelia abuerunt fuero per anutba tenere in Gormaz et in Oxima et in Sancti Stefani; quando prenderunt ipsas kasas maurus, mandavit domno Sancio comite que tenuissent ipsas anutbas in Karazo et in Pennafidele, quomodo totos infanciones faciebant...
} 
that the region's peasant population had to endure. At this stage, state taxation does not seem to have played a significant role. Instead, work renders - whether agricultural or military - seem to have been the main expression of submission to the Count's power, together with the acceptance of his judicial authority. Given the especial strategic situation of the Duero borders, it seems reasonable that military obligations played a more influential role in this region than in the areas north of the river Arlanzón where military stress was occasional. Nevertheless, there is no evidence of local resistance as the new burdens were established, ${ }^{10}$ which is remarkable, since in the early tenth century the Castilian counts largely lacked the resources to enforce their exigencies in every locality across the huge Duero territory. This could only be done with inside cooperation, in which the region's elites were essential, as they had the power to mobilize their communities to meet their new ruler's needs.

Castle-building, of course, was a major burden, both in material costs and manpower, but its weight was probably quite irregular. If the case of Castrojeriz can be taken as an example, erecting the main walls and ramparts (or renewing whatever existing structures there were) must have meant a major effort in a very short time (perhaps one season) to make sure it could immediately resist attack. Further conditioning would arguably span several years and maintenance work would be needed periodically, but these would be much lighter obligations for the population unless the site was taken and destroyed (as happened not infrequently) and needed reconstruction. In any case, there must have been an initial period in which the region's population suddenly became involved in castle making with great intensity, which must have been greatly disruptive for their yearly work cycles. In the absence of large-scale compulsive mechanisms, we must not underestimate the role of bottom-up agency in this process. Burdensome as it was, castle building - like many other defence-related obligations - was highly symbolic, quite different from other kinds of collective work renders, especially in a newly incorporated region. Together with the fear of a potential military threat, it surely had the power to excite people's feelings of belonging to a collective body with which they could identify, so we must allow for some degree of enthusiasm that could well fade out after the initial impulse. This factor may have played its part in other processes of sudden intensification of warfare and castle construction, as in King Alfred's Wessex in the late ninth century.

The strongest motivation, to be sure, was that of the region's elites, whose leading local position allowed them to re-direct community efforts to meet those goals. When the Castilian army was summoned to fonsado, it was the local elites that had to help the Count's officer in organizing the levy before joining the army. This often meant gathering a large party of fighting men and bringing them to whichever part of the county was under threat to counteract Muslim raids, as in the 939 campaign against Simancas, described by the First Castilian Annals and Ibn Hayyan. ${ }^{11}$ Arabic sources are more explicit than Latin ones on Castilian offensive raids southwards, which were usually small-scale looting operations, although they could occasionally scale up and proceed well into the Caliphate's territory (Sánchez-Albornoz 1968, 417-418). Taking part in such raids was an occasion for displaying military abilities and, of course, sharing in the booty. Likewise, carrying out surveillance ( $a n u b d a$ ) became a specific task for the local elites, which reinforced their leading military role before their communities. For those elites, investing in the new order meant a landscape of opportunity.

\footnotetext{
${ }^{10}$ The many acts of opposition to the Count recorded in the aforecited document of $c .1030$ (San Juan de la Peña, $\mathrm{n}^{\circ} 54$ ) belong to $995-1017$ and respond to a different rationale.

${ }^{11}$ Anales Castellanos I, s. a. 939 (ed. by Gómez Moreno 1915); Al-Muqtabis, V, 293-303 (ed. by Ibn Hayyan 1981).
} 
The military situation of the Duero region and the whole organization of warfare could have the effect of reinforcing the division of labour within local communities, by ascribing to their elites specialized tasks that in the long run could make them relatively richer, and generate mechanisms of more intense surplus extraction from the community to provide for the new needs. This would not turn all local leaders - who probably were no more than relatively rich farmers - into non-cultivators overnight, but it could put them in a comparatively better position to seek higher social horizons by marking themselves out from their fellow men, replicating aristocratic life-styles and trying to enter the Count's or some aristocrat's service. It is not possible to follow all of these threads here, so in the last section of this paper discussion will focus on one such possibility: the erection of local towers.

\section{Tower-Building and Social Mobility: The Ghost Towers of Early Castile}

The defence system of the Castilian County's southern border consisted, as described above, of two main types of fortresses: major strongholds and watchtowers. There was, however, probably a third layer of defended sites which were not part of the overall defence system, but of more local significance. Evidence for such local fortresses whether sought in place-names, charters or archaeology - is extremely elusive, but worth pursuing.

A layer of village names in medieval Castile include terms indicating fortifications, like turris, castrum, castrellum or-less frequently-castellum. Such names are sometimes preserved in modern place names, such as Castrojeriz (<Castrum Sigerici), while others are known from references in charters to currently deserted settlements (see the place-name index in Martínez Díez 1987, 403-424). Such place-names are always a minority, about $3.2 \%$ of the 1,737 settlements recorded in Martínez Díez's survey (which is limited to the modern province of Burgos). Of this small group, however, $40 \%$ of place names share a common structure: 'fortification term' + personal name, for instance: Tornadijo (Torre de Atilio) or Tordómar (Torre de Agómar). The 'fortification term' may be castrum - usually in its diminutive form castrellum - (9 cases) or, more often, torre and its diminutive torrecilla (14 cases). In general, both groups concentrate in the south of the county, but the 'torre' + name group is consistently southerly: all cases occur south of the Arlanzón. Many of these names were probably in use in the tenth century, although, given the nature of the textual evidence, we cannot be sure that this is always the case. For example, the now deserted village called Torre de Doña Imblo, in the alfoz of Belbimbre, is first recorded in 1175 (Martínez Díez 1987, 297), too late to argue that the place name dates back to the tenth century. By contrast, other cases are clearer. The best recorded is Torresandino, on the river Esgueva, discussed in detail by Vázquez Álvarez (1999, 362-363). This place is cited in a 948 charter as a reference to locate a donated church: ... aecclesia Sancti Petri et Pauli qui est sita in Augseba, iuxta Torre quem ferunt Domno Sindino... (Cardeña, $\mathrm{n}^{\circ}$ 61). Two other charters of 950 and 958 record a man called Alfonso Sendínez (that is Alfonso, son of Sendino) holding property in nearby Tubilla (Cardeña, $n^{\circ} 74$ and 93). The evidence gathered by Vázquez Álvarez makes clear that Alfonso Sendínez was of non-peasant status, arguably a nobleman, though hardly of the highest kind. If his connection with the place-name is correct, as it seems, this points to another high-status character called Sendino (dominus Sendinus) who gave his name to a tower sometime in the first third of the tenth-century (Alfonso Sendínez was already married in 950), and whose son could lead a life with the material marks of a petty aristocrat. A similar case is a place cited in 952 as Castrello de Munio Romaniz (Cardeña, 
$\mathrm{n}^{\mathrm{o}}$ 82), which can be associated with Romani Munioz, an aristocrat of the following generation recorded in 963, this time with clearly higher family connections (Cardeña, $\mathrm{n}^{\circ}$ 110 and Álvarez Borge 1996, 29-30).

With a few exceptions, most of the persons mentioned in these kinds of placename are utterly obscure. Their names cannot be related to families of an aristocratic character. Moreover, instances bearing status marks like domnus, or the mention of a double name (personal+patronimic) are a minority. Especially in 'tower' place names, the persons involved seem to be ordinary locals (Torre de Apre, Torre de Moronta, Torre de Feles) and not infrequently they have Arabic names (Torre de Agomar, Torre de Abolabaza, Torre de Abolmondar, Torre de Chave), which is a standard feature of personal names among the population of the Duero area, but much less usual among the Castilian aristocracy. Especially interesting is the abovementioned document of ca. 1030 (San Juan de la Peña, $n^{\circ}$ 54) which, referring to events of the late tenth century, mentions three villages called Torre de Guisando, Torre de Abolabaza and Torre de Abolmondar. All of these villages seem to have been controlled by the local elites (which the document calls infanzones). By contrast, a fourth settlement which was wholly controlled by the Count of Castile was called Torreciella, with no further qualifications.

Of course, the number of place-names that fit this model is very low. However, a similar structure occurs with other prefixes, chiefly 'villa', for instance: Villasur (Villa Assur), Villazate (Villa de Zate) or Villovela (Villa Vela). It seems that naming a settlement by reference to a local leading person was frequent practice, and we cannot be sure that only when the prefix was 'Turris' or 'Castrello' did such persons possess a fortified place. In fact, even when the settlement's name does not refer to a tower, minor place names can help identify the existence of such sites in many Castilian villages which - by one reason or another - did not become a part of the main settlement's name, but are preserved as named landscape features. These have sometimes been the subject of surface recognition and study. Together with proto-historic hill-forts and later medieval castles and towers, there seems to exist a layer of sites of strictly local relevance, which especially in northern Castile - tend to be interpreted as long-established community structures, the nodes of small territorial units comprising a few lowland hamlets (Martín Viso 2000, 2006). However, the southern sites of the kind I have discussed are better understood as erected by members of the local elite in an attempt to intensify control over their communities and to present themselves as fit for higher social recognition. With few exceptions, most must have been obscure people, who never made it into the aristocracy. Neither their memory, nor their towers have been preserved.

\section{Conclusions}

Our knowledge of the defensive structures of tenth-century Castile awaits much further work, especially from archaeology. We know too little about the County's main fortresses and their relationship to settlement hierarchy networks that were emerging in that period. Likewise, we can still only hypothesize the existence of a system of dependent watchtowers, arguably manned by local communities according to the system of military obligations described above. Finally, there has not yet been an interest in detecting and defining the physical character of sites like the 'turres', which could work as pointers to an intensification of status differences following the region's incorporation to the Asturian Kingdom. However, we can - and must - keep constructing models that try to bring together the patchy evidence at hand and envisage new orientations for future fieldwork. Such models must be subtle enough to explain the intricacies of social and 
political transformations in a period in which a formidable leap in territorial scale and social complexity took place on a very limited temporal scale. These kinds of transformations are bound to trigger conscious reactions by social actors. Top-down and bottom-up agency must be combined to conceptualise the social change that underlay the construction of the defensive buildings considered in this paper, which were not just royal and/or comital impositions, but the result of a complex interaction between different actors seeking their place in a swiftly changing social landscape.

\section{Works Cited}

\section{Primary Sources}

Gil Fernandez, Juan, José Luis Moralejo, and José Ignacio Ruiz de la Peña, J. I., (eds.) 1985. Crónicas Asturianas, Oviedo.

Gómez Moreno, Manuel. 1915. Anales Castellanos, Madrid.

Ibn Hayyan, Abu Marwan Hayyan ibn Khalaf. 1981. Al-Muqtabis, V, in Crónica del Califa 'Abdarrahman III an-Nasir entre los años 912 y 942 (al-Muqtabis V), ed. María Jesús Viguera and Federico Corriente. Zaragoza, 1981.

\section{Secondary Sources}

Abásolo Álvarez, J. A., and Ruiz Vélez, I. 1976. 'El yacimiento arqueológico de Castrogeriz. Avance al estudio de las cerámicas indígenas', Sautuola, 2, 263-80.

Abásolo Álvarez, J. A., Ruiz Vélez, J. I., and Pérez, F. 1983. 'Castrogeriz I: el vertedero de la Colegiata', Noticiario Arqueológico Hispánico, 17, 191-318.

Abels, R. P. 1988. Lordship and military obligation in Anglo Saxon England, Berkeley.

Almagro, A. 2008. 'La puerta califal del castillo de Gormaz', Arqueología de la Arquitectura, 5, 55-77.

Álvarez Borge, I. 1987. 'El proceso de transformación de las comunidades de aldea: una aproximación al estudio de la formación del feudalismo en Castilla (siglos X y XI)', Studia Historica. Historia Medieval, 5, 145-60.

- 1993. Monarquía feudal y organización territorial. Alfoces y merindades en Castilla (siglos X$X I V)$, Madrid.

- 1996. Poder y relaciones sociales en Castilla en la Edad Media. Los territorios entre el Arlanzón y el Duero en los siglos X al XIV, Salamanca.

Arce, J. 2005. Bárbaros y romanos en Hispania, 400-507 A. D., Madrid.

Bohigas Roldán, R., and Lecanda Esteban, J. Á. 2000. 'Tedeja y el control político del territorio del norte burgalés en época tardorromana, visigoda, alto y plenomedieval', in $V$ Congreso de Arqueología Medieval Española, vol. 1, Valladolid, 49-56.

Brooks, N. P. 1971. 'The development of military obligations in eighth- and ninth-century England', in England before the Conquest, ed. Clemoes, P. and Hughes, K., Cambridge, 69-84.

Carr, K. E. 2002. Vandals to Visigoths. Rural settlement patterns in early medieval Spain.

Castellanos García, S., and Martín Viso, I. 2005. 'The local articulation of central power in the north of the Iberian Peninsula (500-1000)', Early Medieval Europe, 13 (1), 1-42.

Cepas Palanca, A. 2006. 'The ending of the Roman City: the case of Clunia in the Northern Plateau', in People and Space in the Middle Ages, 300-1300, ed. Davies, W., Halsall, G. and Reynolds, A., Turnhout, 187-207.

Chavarría Arnau, A. 2007. El final de las villae en Hispania (siglos IV-VII d. C.), Bibliotèque de l'Antiquité Tardive, 7, Turnhout. 
Díez Herrera, C. 1999. 'La organización social del espacio entre la cordillera cantábrica y el Duero en los siglos VIII al XI: una propuesta de análisis como sociedad de frontera', in Del Cantábrico al Duero. Trece estudios sobre la organización social del espacio en los $s$. VIII a XIII, ed. García de Cortázar y Ruiz de Aguirre, J. Á., Santander, 125-55.

Escalona, J. 1987. 'Las prestaciones de servicios militares y la organización de la sociedad feudal castellana: los infanzones de Espeja', Castillos de España, 94, 55-60.

- 1997. 'Acerca de la territorialidad en la Castilla altomedieval: tres casos significativos', in Historia social, pensamiento historiográfico y Edad Media. Homenaje al Prof. Abilio Barbero de Aguilera, ed. Loring García, M. I., Madrid, 217-44.

- 2000-2001. 'Comunidades, territorios y poder condal en la Castilla del Duero en el siglo X', Studia Historica. Historia Medieval, 18-19, 85-120.

- 2002. Sociedad y territorio en la Alta Edad Media castellana: la formación del alfoz de Lara, 1079 vols, British Archaeological Reports, International Series, Oxford.

- 2004. 'Family Memories. Inventing Alfonso I of Asturias', in Building legitimacy. Political discourse and forms of legitimation in medieval societies, ed. Alfonso, I., Kennedy, H. and Escalona, J., Leiden / Boston, 223-62.

- 2006. 'Patrones de fragmentación territorial: el fin del mundo romano en la Meseta del Duero', in Comunidades locales y dinámicas de poder en el norte de la Península Ibérica durante la Antigüedad Tardía, ed. Espinosa, U. and Castellanos García, S., Logroño, 165-200.

Escalona, J., and Reyes Téllez, F. forthcoming. 'Scale change on the border: the county of Castile in the tenth century ', in Scale and Scale Change in the Early Middle Ages: exploring landscape, local society and the world beyond, ed. Escalona, J. and Reynolds, A., The Medieval Countryside, 6, Turnhout.

Escribano Velasco, C., and Balado Pachón, A. 2000. 'Una singular ocupación altomedieval al sur del Duero: los husun de Íscar y Portillo', in V Congreso de Arqueología Medieval Española, vol. 1, Valladolid, 69-76.

Escribano Velasco, C., Balado Pachón, A., and Pascual, C. 2000. 'Análisis del macrorelieve en arqueología medieval: las fortificaciones del Arlanzón, Pisuerga y Duero, de Burgos Simancas', in V Congreso de Arqueología Medieval Española, vol. 2, Valladolid, 77590.

Estepa Díez, C. 1984. 'El alfoz castellano en los siglos IX al XII', En la España Medieval (Estudios dedicados al profesor d. Angel Ferrari Núñez, 1), 4, 305-42.

- 1989. 'Formación y consolidación del feudalismo en Castilla y León', in En torno al feudalismo hispánico. I Congreso de Estudios Medievales, León, 157-256.

- 1992. 'Configuración y primera expansión del reino astur. Siglos VIII y IX', in De Constantino a Carlomagno. Disidentes, heterodoxos, marginados, ed. Lomas, F. J. and Devis, F., Cádiz, 179-95.

- 1996. 'Organización territorial, poder regio y tributaciones militares en la Castilla Plenomedieval', Brocar, 20, 135-76.

- 2002. 'El poder regio y los territorios', in La época de la monarquía asturiana, Oviedo, 451-67.

- 2003. Las behetrías castellanas, 2 vols, Valladolid.

- 2006. 'Fiscalidad de origen militar y concejos de realengo en la Castilla del Becerro de las Behetrías. Dos ejemplos: los pagos al castillo de Burgos y la fonsadera naval', in Fiscalidad de Estado y fiscalidad municipal en los reinos hispánicos medievales, ed. Menjot, D. and Sánchez Martínez, M., Madrid, 3-20.

Fernández Conde, F. J. 1997. 'Relaciones politicas y culturales de Alfonso II el Casto', in Historia social, pensamiento historiográfico y Edad Media: homenaje al Prof. Abilio Barbero de Aguilera, ed. by María Isabel Loring García, Madrid, 597-611.

Fernández Conde, F. J., Suárez, M. J., and Gutiérrez, A. 1997. 'A transición en Asturias. Aproximación historiográfica e percepción do territorio astur na Alta Idade Media', Santiago de Compostela, 391-412.

García de Cortázar y Ruiz de Aguirre, J. Á. 1997. 'El espacio cántabro-castellano y alavés en la época de Alfonso II el Casto', Cuadernos de Historia de España, 74, 101-20.

García Merino, M. C. 1973. 'La evolución del poblamiento de Gormaz (Soria) de la Edad del Hierro a la Edad Media', Boletín del Seminario de Arte y Arqueología, 39, 31-81. 
Gaya Nuño, J. A. 1943. 'Gormaz, castillo califal', Al- Andalus, 8, 431-50.

González de Fauve, M. E. 1964. 'La anubda y la arrobda en Castilla', Cuadernos de Historia de España, 39-40, 5-42.

Gonzalo González, J. M. 2007. El Cerro del Castillo, Bernardos (Segovia). Un yacimiento arqueológico singular en la provincia de Segovia durante la Antigüedad Tardía, Segovia.

Gutiérrez González, J. A. 1995. Fortificaciones y feudalismo en el origen y formación del Reino Leonés (siglos IX-XIII). Valladolid: Universidad de Valladolid.

- 2000. 'Dominio político y territorio en la formación del feudalismo en el norte peninsular. Propuestas y reflexiones', in V Congreso de Arqueología Medieval Española, vol. 2, Valladolid, 629-55.

Halsall, G. 2003. Warfare and society in the Barbarian West, 450-900, London-New York.

Isla Frez, A. 2000. 'Warfare and Other Plagues in the Iberian Peninsula around the Year 1000', in Europe Around the Year 1000, ed. Urbanczyk, P., Warsaw, 233-46.

Larrén Izquierdo, H., Villanueva Zubizarreta, O., Caballero, J., Domínguez Bolaños, A., Misiego Tejeda, J. C., Marcos, G. J., Blanco García, J. F., Sanz, F. J., Martín, M. A., and Nuño González, J. 2004. 'Ensayo de sistematización de la cerámica tardoantigua en la Cuenca del Duero', in Cerámicas tardorromanas y altomedievales en la Península Ibérica : ruptura y continuidad (II Simposio de Arqueología, Mérida 2001), ed. Caballero Zoreda, L., Mateos Cruz, P. and Retuerce Velasco, M., Madrid, 273-306.

Lecanda Esteban, J. Á., Lorenzo Arribas, J., and Pastor Díaz de Garayo, E. 2008. 'Faros y torres circulares: propuestas para el conocimiento de la efectividad del dominio islámico inicial en los territorios del alto Ebro', in Fars de l'Islam. Antigües alimares d'al-Andalus, ed. Martí Castelló, R., Barcelona, 239-86.

Loring García, M. I. 2005. 'La expansión de la servidumbre en el reino de Navarra a mediados del siglo XI: El ejemplo de Terrero', En la España Medieval, 12, 45-62.

Lucas de Viñas, R. 1971. 'Hallazgos medievales en las laderas del castillo de Peñafiel (Valladolid)', Noticiario Arqueológico Hispánico, 12.

Manzano Moreno, E. 1991. La frontera de al-Andalus en época de los Omeyas, Madrid.

Martí Castelló, R., ed. 2008. Fars de l'Islam. Antigues alimares d'al-Andalus, Barcelona.

Martín Viso, I. 1999. 'Organización episcopal y poder entre la Antigüedad Tardía y el Medioevo (siglos V-XI): las diócesis de Calahorra, Oca y Osma', Iberia. Revista de la Antigüedad, 2, 151-90.

- 2000. Poblamiento y estructuras sociales en el norte de la Península Ibérica, siglos VI-XIII, Salamanca.

- 2002. 'Poder político y estructura social en la Castilla altomedieval: el condado de Lantarón (siglos VIII-XI)', in Los espacios de poder en la España medieval, ed. José Ignacio De la Iglesia Duarte, Semanas de Estudios Medievales de Nájera, 12, Logroño, 533-52.

- 2006. 'Central places and the territorial organization of communities: the occupation of hilltop sites in early medieval northern Castile', in People and Space in the Middle Ages (3001300), ed. Davies, W., Halsall, G. and Reynolds, A., Turnhout, 187-208.

- 2008. 'Tremisses y potentes en el nordeste de Lusitania (siglos VI-VII)', Mélanges de la Casa de Velázquez. Nouvelle série, 38 (1), 175-200.

Martínez Díez, G. 1987. Pueblos y alfoces burgaleses de la Repoblación, Valladolid.

- 1998. Colección documental del monasterio de San Pedro de Cardeña, Burgos.

- 2004. El Condado de Castilla (711-1038). La Historia frente a la leyenda, 2 vols, Valladolid.

- 2007. 'Servidumbre, ingenuidad y privilegio: notas a la condición jurídica de las personas en el Reino de León: 910:1157', in Monarquía y Sociedad en el Reinode León. De Alfonso III a Alfonso VII, Fuentes y Estudios de Historia Leonesa, 117, vol. 1, León, 573-674.

Menéndez Robles, M. L. 1991. 'Cerámicas altomedievales en el Valle del Duero: el ejemplo burgalés', in Burgos en la Alta Edad Media. II Jornadas Burgalesas de Historia, Burgos, 457-88.

Pastor Díaz de Garayo, E. 1996. Castilla en el tránsito de la Antigüedad al feudalismo. Poblamiento, poder político y estructura social del Arlanza al Duero (siglos VII-XI), Valladolid. 
Pérez de Úrbel, Fray J. 1951. 'Reconquista y repoblación de Castilla y León durante los siglos IX y X', in La reconquista española y la repoblación del país, Zaragoza, 127-62.

Quirós Castillo, J. A., and Vigil-Escalera Guirado, A. 2006. 'Networks of peasant villages between Toledo and Velegia Alabense, northwestern Spain (V-Xth centuries)', Archeologia Medievale, 33, 79-128.

Reyes Téllez, F. 1997. 'El alfoz de Rubiales en los siglos X al XII: un ejemplo de organización del territorio castellano a orillas del Duero', in Historia social, pensamiento historiográfico y Edad Media. Homenaje al Prof. Abilio Barbero de Aguilera, ed. Loring García, M. I., Madrid, 245-72.

- 2000. Población y sociedad en el Valle del Duero, Duratón y Riaza en la Alta Edad Media, siglos VI al XI : aspectos arqueológicos, E-Prints Complutense, Madrid.

Reyes Téllez, F., and Menéndez Robles, M. L. 1987. 'Sistemas defensivos altomedievales en las comarcas del Duratón- Riaza (siglos VIII-X)', in II Congreso de Arqueología Medieval Españala, vol. 2, Madrid, 631-39.

Sánchez-Albornoz, C. 1950. 'Alfonso III y el particularismo castellano', Cuadernos de Historia de España, 13, 19-100.

- 1968. 'El ejército y la guerra en el reino astur-leonés, 718-1037', in Ordinamenti militari in Occidente nell'Alto Medioevo, Settimane di Studio del Centro Italiano di Studi sull'Alto Medioevo, 15, vol. 1, Spoleto, 293-428.

Ubieto Arteta, A. 1962. Cartulario de San Juan de la Peña, 2 vols, Valencia.

Uribarri Angulo, J. L., Martínez González, J. M., and Leis Muñoz, I. 1987. Primeros asentamientos humanos en la ciudad de Burgos. I. El yacimientos del castillo y cerro de San Miguel, Burgos.

Vázquez Álvarez, R. 1999. 'Castros, castillos y torres en la organización social del espacio en Castilla: el espacio del Arlanza al Duero (siglos IX al XIII)', in Del Cantábrico al Duero. Trece estudios sobre la organización social del espacio en los s. VIII a XIII, ed. García de Cortázar y Ruiz de Aguirre, J. Á., Santander, 351-73.

Vigil-Escalera Guirado, A. 2006. 'El modelo de poblamiento rural en la Meseta y algunas cuestiones de visibilidad arqueológica', in Gallia e Hispania en el contexto de la presencia 'germánica' (ss. V-VII): balances y perspectivas, ed. López Quiroga, J., Martínez Tejera, A. M. and Morín de Pablos, J., British Archaeological Reports, International Series, vol. 1534, Oxford, 89-108.

Villalba y Ruiz de Toledo, F. J. 1996. 'La línea fronteriza castellana en los primeros compases de ocupación territorial', Boletín de la Institución Fernán González, 212, 169-84.

Wickham, C. 2005. Framing the early middle ages, Oxford.

Zozaya Stabel-Hansen, J. 1984. 'El proceso de islamización en la provincia de Soria', in Actas del I Symposium de Arqueología Soriana, Soria, 481-96.

- 2008. 'La trama defensiva del Valle del Duero', in Fars de l'Islam. Antigües alimares d'alAndalus, ed. Martí Castelló, R., Barcelona, 89-124. 